\title{
The Relationship Between Electronic Cashless Policy and Performance of Nigeria Economy
}

\author{
AJAYI, Olakunle Olusola \\ International School of Management (ISM), France
}

\begin{abstract}
This study examines the relationship between electronic cashless policy and performance of Nigeria economy. This study made use of secondary quarterly annual time series data which was gathered from the Central Bank of Nigeria statistical bulletin and Nigerian Inter-Bank Settlement System (NIBSS) from (2009Q4-2018Q4). The study made use of descriptive statistics, unit root test, heteroskedasticity test, bound co-integration test and auto regressive distribution lag test in the first model because of the mixed order of stationarity. It was discovered from auto regressive distribution lag test that POS contribute positively to the economy. The study strongly suggests that since POS device do not have any option for biometric recognition, there is a need for financial institution to incorporate bio-metric recognition in POS machines, buttressing this point there is need for any POS transaction to be validated by the owner of the account via USSD code sent to the account holders' phone or any other form of authentication before POS can validate any transaction.
\end{abstract}

Keywords: Electronic, Payment System, ATM, POS, Short Message Service.

DOI: $10.7176 /$ RJFA/11-4-10

Publication date: February $29^{\text {th }} 2020$

\subsection{Introduction}

Nigeria financial system has undergone several financial restructurings which is aimed at making trade and production easy. As a result of globalization and technological advancement, commercial activities and transactions have gone beyond exchanging physical cash for the purchase of goods and services as payment for these services have gone technological in nature and monetary transactions can now be done electronically. This method of payment was introduced in developed countries with the aim of having a cashless economy by reducing the volume of money in circulation thus strengthening financial inclusion drive in the country of implementation. A cashless economy is one in which financial transactions are done with the use of electronic devices, it's an economy in which physical money is reduced in most transaction, this does not mean cash is no longer in existence but the use of cash for financial transactions are reduced to the barest minimum. Nigeria fully embraced electronic banking system in the early 2000s (Adurayemi 2016), cashless policy brought about increased cybercrime, increased computerization of monetary transactions, electronic payment system and enhanced confidentiality of transactions. In Nigeria, cashless economy was introduced under cashless policy which kickstarted in Lagos Nigeria as at early 2012, (Chizoba and Anthony 2016), this policy took longer time when compared to other developing countries. According to Ajayi and Ojo (2006), a prerequisite for development to take place is when payment system of any nation is secured, affordable and convenient. It is believed that this will propel developing countries to swerve (change) to electronic payment system most especially internet banking and electronic cards payment. The use of paper money is gradually fading away and developing economy have started embracing the use of electronic payment system, transaction friction is absent in a cashless economy and your wallet balance is precisely irrelevant in a cashless economy. A cashless economy provides an environment in which money is not been physically exchanged for goods and services to effectively take place but the use of electronic device which has the capacity of detecting (real time online financial transaction), how much is to be spent and if the owner of such account has the capacity to carry out such transaction. Information technology is very important in the implementation of cashless policy, since cashless policy is not the complete absence of cash but the use of electronic medium to effect payment for goods and services. An optimal use of information technology makes developing countries have speedy economic growth as this helps to ensure decrease in financial exclusion which is known to significantly impact the capacity of a nation to fully harness the benefit of the output of its people.

Information technology (IT) makes the future of financial and service industry more competitive as the day goes by. IT is more than the mere use of computers, it encompasses a wide spectrum of data, how it's been created and how it can be used in the business world, thus we can relate IT to be the technical application of data to reduce transaction cost and time. Information technology has helped banks to have full access to customers information at any point in time, banks IT take different forms which among a few is the electronic payment platform also known as E-payment platform, managed by Interswitch company, Visa international, Master Card Incorporation. This platform makes it possible for customers to effect transactions via any electronic device that is internet enabled from anywhere in the world. Banks IT systems also helps the bank officials to easily detect fraudulent practices that might arise, cash withdrawal can also be done via the E-payment platforms through Automated Teller Machine (ATM) which will reduce the rate at which people stand in the bank hall as well as waiting time. 
Various security measures have been taken in order to protect customers from fraudulent activities because electronic banking systems are prone to hacking, few of which include the introduction of bio-metrics, personal identification number or passwords, finger- print and facial recognition device. The financial system in Nigeria have undergone many changes over time, in order to facilitate easy way to which customers have access to services at any point in time. Several measures are been taken which has resulted in some form of deregulation in the financial sector, new ways are cotinuously emerging emerged on how money could be used to facilitate trade without physically carrying it from one location to the other, the use of internet banking and E-card payment has made payment for goods and services to be easy and less stressful at anytime of the day with a variety of options that suits the purpose and time constraint. The E-banking platform allows customersto perform financial transactions as well as view/fast track the progress of such transaction real time online anytime, anywhere. Electronic payment system is aimed at curbing the negative consequences such as money laundering, corruption, high cost of cash movement by the financial institutions and high surcharge, that arise as a result of carrying huge amount of money for transaction purposes.

\subsection{Statement of Problem}

The increasing adoption of the use of internet banking in response to cashless policy hasresulted in a shift in customer behaviour towards services rendered in the banking hall leading to banks seeing the need to cut down on their operational staff strength. The Central Bank of Nigeria adopted the cashless policy in order to discourage the movement of huge amount of cash which comes with huge risk and cost to the financial institutions as well as comply with international best practices. This is expected to increase efficiency in the financial system of the country with respect to the quality of services rendered and increase expertise in the payment system between commercial banks in the country which will result in better services rendered to customers. The tensed security situation in Nigeria has made it necessary for individuals, corporate bodies, and government to pursue a cashless policy, this will help control fraudulent practices and make all the funds disbursed into the economy to be properly monitored by the appropriate agency.

Digital contents which includes; parking fees, airline fee, ringtones, music, games and transport fees can be purchased via the use of mobile phone or internet banking. Ajayi and Ojo (2006), discovered that a large percentage of Nigerians are unbanked and illiterate as to the use of E-payment for goods and services purchased, this makes the use of paper money (cash) for payment of goods and services important, making the system to be heavily cashbased. Cash transactions impose tremendous costs in the financial system of any economy most especially the banking system of a country, in order to reduce this cost a limit was placed on daily cash withdrawals $(150,000$ on individual account holder while 1,000,000 on corporate account holder), this measure also helps in the efficiency of monetary policy, the introduction of this policy will affect Small And Medium Enterprise negatively because their turnover rate is low, which hinders the performance of Small And Medium Enterprise (SMEs) as majority of the transactions will be done via E-payment platform but SMEs might not have the facility to carry out such activity, even when they have the facility they are still faced with unreliable network problem as the use of the electronic payment channels (POS, internet banking) are reliant on mobile network.

Cashless policy was first launched in Lagos State, Nigeria by the Central Bank of Nigeria in 2012. Before then, a circular was introduced which stipulated daily cash withdrawal limit and deposit limit with the sole aim of reducing the rate at which cash exchanges hands to the barest minimum which makes it possible for other forms of electronic mode of payment to be effected since a cash-based economy is risky and not healthy for development to take place, six payment terminals were licensed by CBN to see that this policy sees broad daylight Other states in the country like Abuja and Port Harcourt followed suit and gradually, cashless policy has come to stay. Several unethical issues arose in the course of implementing this policy, Akhalumeh and Ohioka (2011), discovered that fraudsters use the E-payment platform as a means of perpetuating their evil act. There have been several enlightenment programs that have made it possible for people to embrace cashless policy in Nigeria, but the high cost of securing facilities that will enable the end user effectively make use of this service is not cheap. High cost of accessing the internet, modern telephone facility, computer and infrastructural decay, low literacy level still pose to be a major constraint to the full adoption of this policy by Nigerians.. The cashless policy is also aimed at reducing the proportion of those who are financially excluded from the society by informing them on other channel that financial system has made available for them to perform their transaction without going into the banking hall.

\subsection{Theoretical Review}

Technology Acceptance Model (TAM): This theory basically points out that the introduction of new ways of doing things via the use of technology is very crucial and important, Any advancement in the use of technology should be towards making it useful for the end users to be able to acquit themselves with the use of the technology. It has to be easy for the users from both ends and the designer also has to keep abreast of the potential customers the technology is to benefit. 


\subsubsection{Theory of Consumption Value (TCV)}

This theory has been used in different fields of study ("software by Alpert, (1994), IT artefacts by Turel, Serenko \& Bontis, (2009) and internet banking by Ho \& Ko (2008)") to explain the rationale behind consumers behaving in a certain way when it comes to choosing which particular product they are to make use of from the homogeneous products available to them. The value derived from consuming a particular product motivates the individual consumers to go for that particular product. The values are subcategorized into five which largely depend on each other; conditional value, emotional value, functional value, social value and epistemic value. Since no individual taste, need and want is the same, this will affect their decision which will eventually affect the particular product and service to go for. The mode of payment that is convenient to consumers have made this theory accepted for this study, since the use of any means of payment is dependent of the decision of the consumer (Buyer). The mode of payment is determined by the payment technology disposable to the consumer and the level of satisfaction the consumer derive from any of the available payment mode.

Let's take functional value; This value is pinned to economic utility theory, this simply states that the maximum satisfaction derived from consuming a particular product is a major determinant in selecting that product/ service. In summary the rationale behind selecting any product is economical in nature and based on the price of the product, quality, reliability and performance. Before a consumer decides to use a particular product it must meet his taste and specification, it must also be able to fulfill the reason why it's to be utilized. The utilitarian needs of consumer in this subject matter which represents how well consumers are able to pay for the goods/services conveniently holding constant the cost price of making use of such a facility, how reliable such facility is to be used. Some people feel so comfortable paying via transfer while some don't feel the same way, depending on the kind of goods purchased, some feel very comfortable making cash payment for any transaction.

\subsection{Conceptual Review}

2.2.1 Electronic Banking: This is the use of electronic devices that helps in the transfer of money, these devices connect with the various banks platforms for example Guarantee Trust Bank (GTB) Internet banking application which can be accessed via the use of Phone or computer, GT banks Short Message Service (SMS Code), GT bank Automated Teller Machine (ATM), Point of Sale (POS) and Telegram. The use of this form of payment is extremely fast and efficient, the speed at which money exchange hands is the fastest ever in the evolution of trade. This method of payment eliminates trips to the physical banking hall; it also eliminates the stress of waiting in long queues. The dilemma with the use of this application ranges from, error in transaction process, excessive transfer fee, mistake that might take up to a month to correct from the backend at the bank.

\subsubsection{Forms of E-Payment/ Means of Cash Withdrawal}

a) Internet Banking (E-Banking): Virtually every bank has E-banking App, this App works with internet facility which facilitates customers transactions. The E-platform has an option for user name and personal identification number (PIN), with these two information anyone can access their personal data online, the internet banking facility has service options which expediates financial transaction. According to Adurayemi (2016), customers with this facility can access their account for 24 hours.

b) Short Message Service (SMS) and Unstructured Supplementary Service Data (USSD): These services can be accessed via the use of mobile phones. Banks have varieties of USSD codes for different financial transactions their customers want to execute, this facility enables customers conduct some banking activities such as payment of bills, transfer of funds and checking of financial account transactions.

c) Automated Teller Machine (ATM): The ATM is an electronic device that allows customer of any bank to deposit, transfer and make withdrawals. ATM machines have other facilities that enables customers to make financial transactions smoothly such as payment of household bills and phone bills. ATM machines works with an ATM Cardwhich is encrypted with a personal identification number (PIN) which is required for transaction purposes. The use of this facility attracts a surcharge fee depending on the nature of transaction to be carried out. ATM cards issued by the bank also have a withdrawal daily limit depending on the type of account the holder is keeping with the bank and it attracts a periodic maintenance fee charged to the cardholder's account. ATM machines are mostly found in business areas and urban cities.

d) Point of Sale (POS): POS is a small device that accepts Smart cards or E-Card to make cash withdrawals. This device is found in business environment (supermarket, schools etc.) for payment of goods and services. Recently the trend has it now that POS devices are now used for cash withdrawal and cash transactions because of mobile network problems on internet banking platforms, long queues in the ATM stands and long queues in the banking hall. In another vein, POS devices are now used for criminal activities since a good number of them are not been properly registered and since there is no permanent trace of the point of withdrawal.

\subsubsection{Benefits of Cashless Banking.}

* Reduces risk that are related to carrying of cash

* It expedites cash related transactions

* Gives customers better service options 


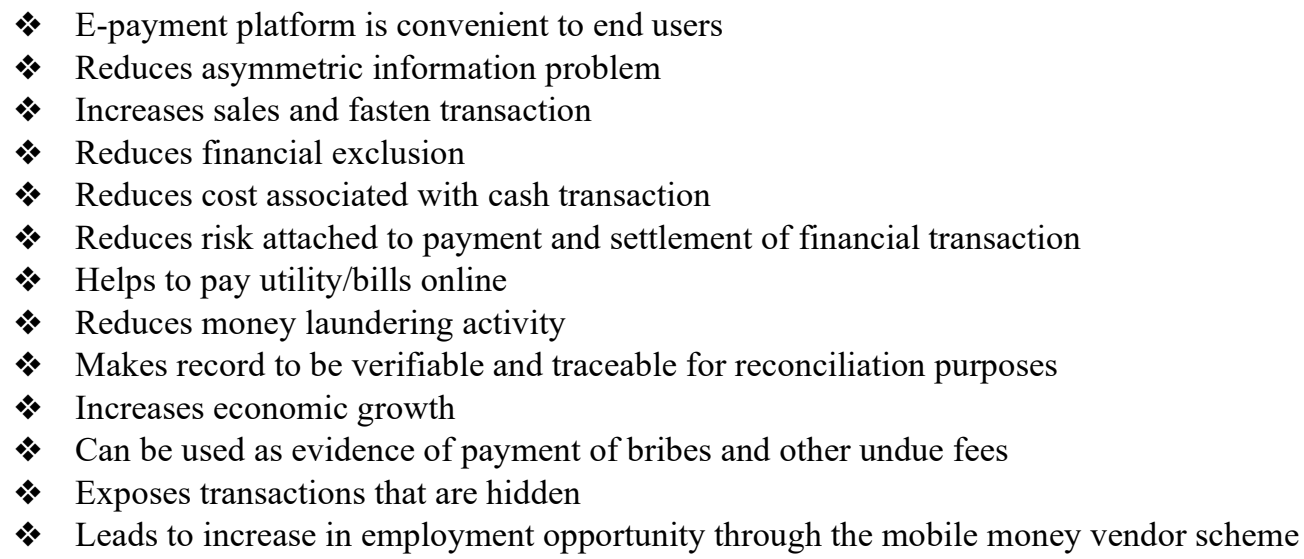

\subsection{Empirical Review}

Martin, Nnamani, Mary and Mgbodile (2014) investigated cashless policy in Lagos Nigeria, the study made use of accidental sampling technique, which they distributed questionnaires to civil servants, traders and students . From the results of the descriptive analysis, it was discovered that $66.6 \%$ of the respondent accepted that this policy helps to reduce corruption and it increases foreign trades in the Nigeria economy, while $22.2 \%$ disclosed that it reduces robbery and $11.1 \%$ accepts that it increases employment opportunities in the country. In general, they discovered that it will help in curbing fraudulent banking practices.

Xiao, Hedman and Runnemark (2015) examined consumers preference on the use of payment system available to them, this research was carried out in Northern Europe (Denmark) The study made use of information on three well established payment technologies (internet banking, cash group and card group) alongside bi-annual payment statistics from Denmark National Statistics Agency and Danish Apex Bank while strongly holding down the theory of consumer consumption value. This study pointed out that four factors affect the channel through which customers can pay for goods and services. The study discovered that the use of card payment induces less pain which eventually makes customers to keep using the card payment system at their disposal, payment technologies also adds value to the customer apart from just satisfying their transitionary need. It was therefore recommended that institutional efforts which will facilitate cashless policy should be put into place. In the same light in the work of Oladimeji and Folayan (2018), they discovered that acceptable information technology helps to increase productivity and performance which makes the market work more efficiently.

Ailemen Akpan, Osuma' Evbuomwan and Ndigwe (2018), investigates how internet banking have helped cashless policy attain its aim and purpose in Nigeria. The study made use of data for a ten-year period which was sourced from Nigeria Interbank Settlement System (NIBSS) and central bank of Nigeria. It was discovered that the volume of currency in circulation has no substantial relationship with the tools associated with electronic banking. Secondly, it was discovered the use of ATM within the review period was the most used facility as regards to other electronic device. The study recommended that there is a need to create awareness programs and the fees associated transaction should be reduced.

Okoye (2018) examined how cashless banking affects unemployment rate in Nigeria, Okoye (2018) opined that cashless banking does not only mean e-banking system but it also accommodates cash-based banking. The study advocates that there is need to share more light on how cash-light banking is beneficial to the entire population at large and how it can contribute to employment. After making use of time series data from 2012-2016 the result of the study showed that cashless banking has not led to unemployment, owing to the fact that this technology needs expertise that are technologically inclined to handle the e-platform (ATM and others) operations other maintenance issues that might arise in the country within the period under review, all this will create employment opportunity as employable graduate will get employed. All this will contribute to economic growth to a great extent, from the result it was also discovered that POS contributed substantially to economic growth from the result of the regression analysis, the study contributed to correcting the negative impression that cashless policy contributes to unemployment instead this policy contributes to employment opportunity in the country, and there is need for workers to be kept abreast with modern trend in the banking sector.

\subsection{Methodology}

This research work made use of quantitative research data. $\mathrm{x}$-post facto research design was also used in the model below with the believe that this methodology would help to have a robust knowledge of the subject matter.

\subsection{Model Specification}

The study made use of quarterly time series data for analysis from 2009-2018, obtained from Central Bank of 
Nigeria Statistical Bulletin and Nigerian Inter-Bank Settlement System (NIBSS). Various diagnostic tests were carried out on the data before proceeding to other tests.

\subsubsection{Functional Equation}

The model below specifies the relationship between the slope and intercept.

$\mathrm{GDP}=\mathrm{f}(\mathrm{INB}, \mathrm{SMS}, \mathrm{ATM}, \mathrm{POS})$

\subsubsection{Econometric Equation}

For econometric and data transformation purpose, the error term is added to equation 1 which can be rewritten as: $\mathrm{D}(\mathrm{GDP})=Ж_{\mathrm{o}}+Ж_{1} \mathrm{D}(\mathrm{INB})+Ж_{2} \mathrm{D}(\mathrm{SMS})+Ж_{3} \mathrm{D}(\mathrm{ATM})+Ж_{4} \mathrm{D}(\mathrm{POS})+\varepsilon_{\mathrm{t}}$

Apriori $=Ж_{1},>0, Ж_{2},>0, Ж_{3},>0, Ж_{4}>0$

Where:

GDP $=$ Gross Domestic Product

$\mathrm{INB}=$ Internet Banking

SMS $=$ Short Message Service

$\mathrm{ATM}=$ Automated Teller Machine

POS $=$ Point of Sale

$\mathrm{D}=\quad$ Difference Data

$\Psi_{0}=$ Constant Parameter

$\varepsilon=$ Error Term

Because of the missed order of stationarity, the Autoregressive distributive lag (ARDL) mechanism is appropriate. On this premise, Autoregressive distributive lag (ARDL) mechanism could be designed thus:

$$
y t=ß o+\beta 1 t \sum_{i-1}^{p} \varnothing i y t-1+\beta x t+\sum_{i=0}^{p} \beta_{1}+\Delta x t-1+\pi t
$$

Where

$\mathrm{x}_{\mathrm{t}}=\quad$ Dimension of $1(1)$ variable not stationary

$\beta_{1}=$ Matrix which makes autoregressive process stable

$\pi t=$ error term

\section{Analysis of Data}

4.1 Descriptive Statistics

Table 4.1 Descriptive Statistics Result

\begin{tabular}{|l|c|c|c|c|c|}
\hline & GDP & ATM & POS & INB & SMS \\
\hline Mean & 4582598. & 1084.579 & 197.1754 & 44.17393 & 166.0957 \\
\hline Median & 23240.31 & 1021.735 & 108.5000 & 23.68500 & 114.2350 \\
\hline Maximum & 35230608 & 1832.550 & 714.0000 & 340.0000 & 593.0000 \\
\hline Minimum & 16450.36 & 454.7900 & 1.870000 & 6.380000 & 1.080000 \\
\hline Std. Dev. & 11416867 & 418.9526 & 202.7559 & 70.55610 & 154.7210 \\
\hline Skewness & 2.073200 & 0.164046 & 1.195108 & 3.335655 & 1.130366 \\
\hline Kurtosis & 5.357360 & 1.788151 & 3.330094 & 13.44228 & 3.632448 \\
\hline & & & & & \\
\hline Jarque-Bera & 26.54141 & 1.838926 & 6.792441 & 179.1389 & 6.429382 \\
\hline Probability & 0.000002 & 0.398733 & 0.033500 & 0.000000 & 0.040168 \\
\hline & & & & & \\
\hline Sum & $1.28 \mathrm{E}+08$ & 30368.22 & 5520.910 & 1236.870 & 4650.680 \\
\hline Sum Sq. Dev. & $3.52 \mathrm{E}+15$ & 4739075. & 1109969. & 134410.4 & 646341.6 \\
\hline \multicolumn{2}{|c|}{} & 28 & & & \\
\hline Observations & 28 & & 28 & 28 & \\
\hline
\end{tabular}

Source: Authors Compilation from E-views 10

The mean value measures the overall average value in the model, the highest mean value of gross domestic product (GDP) is seen to be 4582598, followed by automated teller machine (ATM) with 1084.579, then point of sale (POS) having 197.1754, then short message service (SMS) 166.0957 and finally, internet banking (INB) 44.17393. The normality in the model can be ascertained via the Jarque-Bera statistics, it can be seen that GDP, POS, INB and SMS have a probability that is less than $0.05 \%$, The standard deviation (SD) values measures the point at which each variable deviate from the mean, from the above it can be deduced that GDP is the most volatile of all variables with a 11416867 standard deviation value, followed by ATM having an SD value of 418.9526, then POS having a value of 202.7559, then SMS has an SD value of 154.7210, the value of the least point of deviation is INB with $70.55610 \mathrm{SD}$ value. One variable is said to be leptokurtic in nature (ATM) 1.788151 variable is said to be platykurtic in nature this indicates the Kurtosis value is less than 3 indicating a thin tail compared to 
the standard normal distribution, which indicate it tend to have less major fluctuation. (GDP) 5.357360 and (POS) 3.330094 (INB) 13.44228 and (SMS) 3.632448 are said to be leptokurtic in nature, because their kurtosis value is larger than 3.

\subsection{Stationarity Test}

The first model made use of quarterly quantitative data (every-three month) from 2009-2018, the year selected under investigation was selected based on the data available, the ADF test was conducted in order to ascertain the level of stationarity of the data.

Table 4.2 Augmented Dickey-Fuller (ADF)

\begin{tabular}{|c|c|c|c|}
\hline $\begin{array}{l}\text { Augmented Dickey- } \\
\text { Fuller (ADF) } \\
\text { D(GDP) }\end{array}$ & $\begin{array}{r}\text { Test Critical Values: } \\
3.615588 \\
-2.941145 \\
-2.609066\end{array}$ & $\begin{array}{c}\text { T-Statistic - } \\
\mathbf{5 . 6 3 9 2 1 3} \\
\text { D (GDP (-1))) - } \\
0.994554\end{array}$ & $\begin{array}{c}\text { Prob. }{ }^{*} \\
0.0000 \\
\text { Stationary at 1(1) }\end{array}$ \\
\hline $\begin{array}{c}\text { Augmented Dickey- } \\
\text { Fuller (ADF) } \\
\text { D(INB) }\end{array}$ & $\begin{array}{r}\text { Test Critical Values: } \\
3.615588 \\
-2.941145 \\
-2.609066 \\
\end{array}$ & $\begin{array}{c}\text { T-Statistic } \\
\mathbf{8 . 8 9 1 6 1 7} \\
\text { D (INB (-1))) - } \\
1.461592 \\
\end{array}$ & $\begin{array}{c}\text { Prob. }{ }^{*} \\
0.0000 \\
\text { Stationary at } \mathbf{1 ( 0 )}\end{array}$ \\
\hline $\begin{array}{c}\text { Augmented Dickey- } \\
\text { Fuller (ADF) } \\
\text { D(SMS) }\end{array}$ & $\begin{array}{r}\text { Test Critical Values: } \\
3.679322 \\
-2.967767 \\
-2.622989 \\
\end{array}$ & $\begin{array}{c}\text { T-Statistic } \\
\mathbf{3 . 7 1 7 8 5 1} \\
\mathrm{D}(\mathrm{SMS}(-1)))- \\
3.482310 \\
\end{array}$ & $\begin{array}{c}\text { Prob. }{ }^{*} \\
0.0001 \\
\text { Stationary at } \mathbf{1 ( 0 )}\end{array}$ \\
\hline $\begin{array}{c}\text { Augmented Dickey- } \\
\text { Fuller (ADF) } \\
\text { D(ATM) }\end{array}$ & $\begin{array}{r}\text { Test Critical Values: } \\
3.615588 \\
-2.941145 \\
-2.609066 \\
\end{array}$ & $\begin{array}{c}\text { T-Statistic } \\
\mathbf{7 . 5 3 3 7 3 3} \\
\text { D (ATM (-1))) - } \\
0.994554 \\
\end{array}$ & $\begin{array}{c}\text { Prob. }{ }^{*} \\
0.0000 \\
\text { Stationary at 1(1) }\end{array}$ \\
\hline $\begin{array}{c}\text { Augmented Dickey- } \\
\text { Fuller (ADF) } \\
\text { D(POS) }\end{array}$ & $\begin{array}{r}\text { Test Critical Values: } \\
3.632900 \\
-2.948404 \\
-2.612874 \\
\end{array}$ & $\begin{array}{c}\text { T-Statistic } \\
\mathbf{6 . 3 2 6 4 1 7} \\
\mathrm{D}(\operatorname{POS}(-1)))- \\
3.081560\end{array}$ & $\begin{array}{c}\text { Prob. }{ }^{*} \\
0.0000 \\
\text { Stationary at 1(1) }\end{array}$ \\
\hline
\end{tabular}

Source: Authors Compilation from E-views 10

The table above shows that the variables are stationary at first difference and second difference, subsequently the critical value at $5 \%$ level is less than the computed value, making us to accept stationarity at order $1(0)$ and order 1(1). The mixed order of integration/stationary trend is a prerequisite to conducting ARDL bond test.

Table 4.3 Heteroskedasticity Test

Heteroskedasticity Test: Breusch-Pagan-Godfrey

$\begin{array}{llll}\text { F-statistic } & 3.094796 & \text { Prob. F(12,24) } & 0.0789 \\ \text { Obs*R-squared } & 22.47538 & \text { Prob. Chi-Square(12) } & 0.3325 \\ \text { Scaled explained SS } & 12.31269 & \text { Prob. Chi-Square(12) } & 0.4209\end{array}$

Source: Authors Compilation from E-views 10

In order for the model to fulfill the classical linear regression model assumption (CLRMA) the Heteroskedasticity test has to be conducted. This test is used to ascertain if the residual of the model is normally distributed or not. From the result above the value of it can be seen that the Observed $\mathrm{R}^{2}$ exhibit a coefficient of $(0.3325)$ which is greater than $0.05 \%$. 
Table 4.4 Bound Test Co-Integration Output

ARDL Bounds Test

Date: 04/23/19 Time: 15:30

Sample: 2009Q4 2018Q4

Included observations: 37

Null Hypothesis: No long-run relationships exist

\begin{tabular}{lll}
\hline Test Statistic & Value & $\mathrm{k}$ \\
\hline F-statistic & 15.83152 & 4 \\
\hline
\end{tabular}

Critical Value Bounds

\begin{tabular}{lcc}
\hline Significance & I0 Bound & I1 Boun \\
\hline & & \\
$10 \%$ & 2.45 & 3.52 \\
$5 \%$ & 2.86 & 4.01 \\
$2.5 \%$ & 3.25 & 4.49 \\
$1 \%$ & 3.74 & 5.06
\end{tabular}

Source: Authors Compilation from E-views 10

The long run co-association needed to be determined before the bond co-integrating test is therefore employed, having in mind the decision rule which states that the null hypothesis is rejected if the F-statistics is greater than the upper and lower bond statistics at all levels displayed in the result. Thus the study concludes that a long run association is noticeable between all the employed variable, but if the F-statistics is lesser than the upper and lower bond statistics at all levels we accept the null hypothesis. It can be seen that the F-statistics which is 15.83152 is far higher than the bound Critical Value both at lower and upper limit. 
Table 4.5 ARDL Long Run Coefficient

Dependent Variable: D(GDP)

Method: ARDL

Date: 04/23/19 Time: 15:29

Sample (adjusted): 2009Q4 2018Q4

Included observations: 37 after adjustments

Maximum dependent lags: 2 (Automatic selection)

Model selection method: Akaike info criterion (AIC)

Dynamic regressors (2 lags, automatic): D(INB) D(SMS) D(ATM) D(POS)

Fixed regressors: $\mathrm{C}$

Number of models evalulated: 162

Selected Model: ARDL(1, 2, 2, 1, 2)

\begin{tabular}{crrrr}
\hline Variable & Coefficient & Std. Error & t-Statistic & Prob. $^{*}$ \\
\hline D(GDP(-1)) & & & & \\
D(INB) & 0.275948 & 0.153961 & 1.792325 & 0.0857 \\
D(INB(-1)) & -10365.75 & 17932.45 & -0.578045 & 0.5686 \\
D(INB(-2)) & 8496.996 & 23496.38 & 0.361630 & 0.7208 \\
D(SMS) & -95481.67 & 45434.79 & -2.101510 & 0.0463 \\
D(SMS(-1)) & -24852.33 & 29431.16 & -0.844422 & 0.4068 \\
D(SMS(-2)) & -20502.17 & 31128.67 & -0.658627 & 0.5164 \\
D(ATM) & -166115.0 & 33858.40 & -4.906169 & 0.0001 \\
D(ATM(-1)) & -10615.41 & 8302.800 & -1.278534 & 0.2133 \\
D(POS) & 10582.35 & 7861.983 & 1.346015 & 0.1909 \\
D(POS(-1)) & 44102.36 & 56196.45 & 0.784789 & 0.4403 \\
D(POS(-2)) & 72248.21 & 60489.79 & 1.194387 & 0.2440 \\
C & 86296.08 & 56393.31 & 1.530254 & 0.1390 \\
& -147200.4 & 740845.1 & -0.198693 & 0.8442 \\
\hline R-squared & 0.776399 & Mean dependent var & & 773572.2 \\
Adjusted R-squared & 0.664599 & S.D. dependent var & & 4855481. \\
S.E. of regression & 2811994. & Akaike info criterion & & 32.80652 \\
Sum squared resid & $1.90 E+14$ & Schwarz criterion & & 33.37252 \\
Log likelihood & -593.9207 & Hannan-Quinn criter. & & 33.00607 \\
F-statistic & 6.944521 & Durbin-Watson stat & & 2.359470 \\
Prob(F-statistic) & 0.000031 & & & \\
\hline Source: Authors Compitation from & & & \\
\hline
\end{tabular}

Source: Authors Compilation from E-views 10

\section{Global Statistics}

From the table above, the adjusted $\mathrm{R}^{2}$ which measures coefficient of determination exhibits a coefficient of 0.776399 which suggest that the independent variables used in this study jointly account for about $78 \%$ variation in the dependent variable while the value of the Durbin Watson stood at 2.359470 which suggest absence of autocorrelation. The F-statistics alongside the P-value established that the variables chosen to proxy electronic payment system are significant in stimulating Nigeria Economy.

The dynamic relationship between the variable in the long run showed that internet banking $\mathrm{D}$ (INB) has a negative (-10365.75) and insignificant relationship (P-value 0.5686$)$ with gross domestic product $\mathrm{D}(\mathrm{GDP})$, but in the long run $\mathrm{D}(\mathrm{INB}(-1))$ has a positive co-efficient of 8496.996 but an insignificant relationship $(0.7208)$ with D(GDP). At lag (-2) D(INB has a negative (co-efficient of -95481.67) but significant relationship (0.0463) with $\mathrm{D}(\mathrm{GDP})$. On two occasions $\mathrm{D}(\mathrm{INB})$ has an insignificant relationship with $\mathrm{D}(\mathrm{INB})$ but at $\mathrm{D}(\mathrm{INB}(-2))$ a significant relationship is discovered. As at lag $(-1)$ we discovered that money laundering has been curtailed to a very large extent since the introduction of internet banking (cashless policy), officials that want to indulge in this practice have been caught over the past years, there is transparency and corruption related to banking practice is also mitigated. The negative contribution discovered agrees with the work of Okoye (2018) that in the short and long run, internet banking does not contribute to economic growth, the financial system is not technologically changing with the developed countries and this has an adverse effect on how internet banking contributes to growth in the long run, the network providers also contribute to the decline with the use of this facility as response to their services is slow, moreover the level of their illiteracy in Nigeria is on the high side.

In the short run and lag (-1), short message service D(SMS) and D(SMS(-1)) has a negative (co-efficient of $24852.33,-20502.17$ ) and insignificant relationship (p-value of $0.4068,0.5164)$ with $\mathrm{D}(\mathrm{GDP})$, but a negative (co- 
efficient of -166115.0) and significant relationship (p-value of 0.0001) was discovered between D(SMS(-2)) and $\mathrm{D}($ GDP) in lag (-2). It was discovered both in the long and short run, short message service (SMS) does not contribute significantly to GDP this arises because of the network problem (delay in response, network shortage) that users of this facility encounter while using any of the telecommunication facility available to them, but a significant relationship was attainable in lag $(-2)$ and taking a closer look at its contribution to economic growth we find out that in the long run at lag (-2) precisely we discover that there is a sharp decrease as to the rate at which its contributing negatively. This study further recommends that if all difficulty that might arise in the short run can be handled correctly and speedily there is every likely hood that SMS will contribute significantly on the long run.

ATM has a negative (-10615.41) and insignificant relationship (0.2133) with GDP in the short run, this means for every one percent increase in the use of ATM there will be a reduction of about $-10615.41 \%$ in GDP, the cost of installing and maintaining one ATM is high and these machines are located only in catchment environment, Mustapha (2018) ATM contributes to deterrent to the operation of the bank. while in the long run ATM (-1) has a positive (10582.35) but insignificant relationship (0.1909) with GDP, this means for every one percent increase in the use of ATM, it will contribute about $10582.35 \%$ to GDP, suggesting that in the long run the use of ATM cannot be neglected and its very vital to the growth of any business, this result accepts the findings of Ailemen' et al (2018) who discovered that the use of ATM contribute to growth in the economy. Adurayemi (2016), discovered that ATM is a major tool that is used by all class of people (learned, rich, unlearned and poor) to facilitate their financial need and helps the less inclusive set of persons to be financially inclusive, according to Adurayemi (2016) ATM is the most common means of effecting cashless policy.

It was discovered in the short run from the result above that point of sale (POS) has a positive (co-efficient of 44102.36) and insignificant relationship (p-value of 0.4403$)$ with gross domestic product, while in lag $(-1)$ ) $\mathrm{D}$ (POS) has a positive (co-efficient of 72248.21) but insignificant relationship ( $p$-value of 0.2440) with GDP, it was discovered in lag (-2) that $\mathrm{D}(\mathrm{POS}(-2))$ has a positive (co-efficient of 86296.08) and an insignificant (p-value of 0.1390$)$. The positive co-efficient recognized is noticeable because bank customers that make use of POS is on the increase on a daily basis, this increase is as a result of an increase in the number of persons that make use of POS, it discovered that making payment or withdrawing via the use of POS is fast and less stressful, POS facility also reduces the stress of carrying money from one point to another, it also makes payment for services to be tracked via the receipt given if need be for reconciliation purposes. The point of sale terminal fee favor's the business men and reduces the unforeseen risk attached to them holding cash for business transaction. The result obtained accepts the findings of Ailemen' et al (2018) who discovered positive relationship between POS and GDP in the two-model analysis, this same relationship is discovered in the work of Okoye (2018) and Mustapha (2018). The findings from the analysis above contradicts the findings of Adeoti and Osotimehin (2012), but in agreement with the finding of Okoye and Ezejiofor (2013), who discovered that cashless policy fight against cash-carrying related challenges and bank performance increased as a result of the introduction of cashless policy (Mustapha 2018).

\section{Summary, Concussion and Recommendation}

This study made use of time series data obtained from Central Bank of Nigeria Statistical Bulletin and Nigeria Inter-bank Settlement System (NIBSS) to investigate the relationship between electronic cashless policy and performance of Nigeria economy.

In the course of this research, it was discovered that the banks (Workers) decides to hoard money meant for withdrawals via the ATM and make the ATM redundant with the intention of trading with hoodlums. This will necessitate bank customers to make use of the nearest alternative which is POS for cash withdrawal or transfer. The issue of transfers has reduced the frequency of customer visits to banking halls leading to a significant reduction in work pressure on banks operations staff consequently a reduction in the staff strength of some banks.. POS machines do not have any biometric detection control or tracking device to exactly know who owns the machine that was used to withdraw cash and the rate of usage of this device for criminal activity is on the increase, it was discovered from the study that transactions are carried out faster when using internet banking facility, conclusively this paper accepts the point of view that cashless policy helps in reducing excessive circulation of paper note, it also reduces the monitoring burden of managing cash by the CBN, this policy assists monetary authority to regulate money supply and the volume of money in circulation, another benefit achieved related to this policy is that there is transparency and fraudulent practice related to cash transaction can be easily detected by specialist with proofs since every transaction can be traceable to some sort of records. This policy helps to bridge the gap between the proportion of those that are excluded (not able to access) from financial services due to reasons beyond their control, greater risk is faced by low-income consumers as they suffer more as a result of financial exclusion (Bayero 2015), all these are geared towards achieving full financial inclusion. Finally, this policy helps in modernization of payment system which brings the country to pace with developed country globally. 


\section{Recommendation}

Based on the findings in model above, the following recommendations were made;

i. POS machines do not have any option for biometric recognition, this paper strongly suggests that there is a need for financial institution to incorporate bio-metric recognition in POS machines. Buttressing this point, there is a need for any POS transaction to be validated by the owner of the account via USSD code sent to the account holders' phone or any other form of authentication before POS machine can validate any transaction.

ii. Transaction cost of using any of the electronic mode of payment should not only be reviewed, there is a need to create awareness as to the use of such facility. It should be customer friendly and more importantly there is need for the banks to periodically make development/changes on such facilities.

iii. Bank officials should immediately desist from colluding with hoodlums with POS machines at ATM terminals to make the terminals non-functional especially in rural areas so that bank customers then turn to hoodlums to carry out their transactions. This study strongly recommend that private companies should take up the responsibility of providing private pool of ATMs in various locations to make it easy for those that need liquid cash to have immediate access to it.

iv. Financial institutions should partner with business firms (private or public) to design facilities that will help to ease payment for goods and services in their respective companies, the small and medium scale enterprise must not be neglected as well.

v. Financial institution should beef up the security measures put in place to safeguard the end users from unauthorized users, these institutions should call back POS machines that are not properly registered as this will reduce unwanted incidence of criminals using this to carry out their evil intentions., More POS machine should be given out as they contribute significantly to expediting the implementation of cashless policy in the country.

vi. There is a need for Global System for Mobile Communications (GSM) operators to create more robust platforms that will enable customers to have access to banking services. This will reduce asymmetric information and transaction cost as this can help to ease the stress of payment for goods and services.

vii. There is a need for more effective and reliable database for warehousing data on financial transactions especially across various channels so as to facilitate easy tracking and reconciliation of suspicious or fraudulent transactions in the overall interest of customers and the banks. This calls for more investment in data infrastructure by the banks, the benefit of this investment will definitely pay off in the short and long term.

\section{References}

Adurayemi, A.C (2016) Cashless policy and its effects on the Nigerian economy. European Journal of Business, Economics and Accountancy. (4)2.

Adurayemi. A.C (2016) Cashless policy and its effects on the Nigerian economy. European Journal of Business, Economics and Accountancy. (4) 2.

Ailemen I O. Akpan E. Osuma G O. Evbuomwan G \& Ndigwe. C (2018) Electronic banking and cashless policy in Nigeria. International Journal of Civil Engineering and Technology (IJCIET). (9), 10.

Bayero, M.A (2015) Effects of cashless economy policy on financial inclusion in Nigeria: An exploratory study. Global Conference on Business \& Social Science-2014, GCBSS-2014, 15th \& 16th December,49-56. Kuala Lumpur

Bayero. M.A (2015). Effects of cashless economy policy on financial inclusion in Nigeria: An exploratory study. Procedia - Social and Behavioral Sciences $17249-56$.

Marco, A. \& L. Bandiera (2004) Monetary policy, monetary areas and financial development with electronic money, IMF Working Study, IMF.

Martin C. E. Nnamani J. N. Mary I. M \& Mgbodile. C.C. (2014). The impact of central bank of Nigeria cashless policy in Nigeria economy. IOSR Journal of Business and Management (IOSR-JBM). e-ISSN: 2278-487X, pISSN: 2319-7668. (16), 12. 84-95.

Mustapha. S.A (2018) E-payment technology effect on bank performance in emerging economies-evidence from Nigeria. Journal of Open Innovation. (4), 43.

Okoye, A.P (2018). Effect of cashless banking on unemployment rate in Nigeria. Asian Journal of Economics, Business and Accounting. (4), 6.1-18.

Okoye, P.V.C., \& Ezejiofor, R. (2013). An appraisal of cashless economy policy in development of Nigerian economy. Research Journal of Finance and Accounting, 7 (4), 237-252.

Oladimeji, T.T and Folayan, G.B (2018) ICT and Its Impact on National Development In Nigeria: An Overview. Research \& Reviews: Journal of Engineering and Technology. (7) 1

Xiao.X, Hedman.J and Runnemark.E (2015). Use of payment technology: a perspective based on theory of consumption value. Twenty-Third European Conference on Information Systems (ECIS), Münster, Germany. ECIS 2015 Research-in-Progress Papers. 